\title{
The Importance of Agriculture-Dominated Landscapes and Lack of Field Border Effect for Early-Succession Songbird Nest Success
}

\section{Importance des paysages dominés par l'agriculture et absence d'effet des lisières sur le succès de nidification de passereaux de début de succession}

\author{
$\underline{\text { Jason D. Riddle }}^{1}$ and Christopher E. Moorman ${ }^{2}$
}

\begin{abstract}
In recent decades, many early-succession songbird species have experienced severe and widespread declines, which often are related to habitat destruction. Field borders create additional or enhance existing early-succession habitat on farmland. However, field border shape and the landscape context surrounding farms may influence the effectiveness of field borders in contributing to the stabilization or increase of early-succession bird populations. We examined the influence of linear and nonlinear field borders on farms in landscapes dominated by either agriculture or forests on nest success and Brown-headed Cowbird (Molothrus ater) brood parasitism of Indigo Bunting (Passerina cyanea) and Blue Grosbeak (Passerina caerulea) nests combined. Field border establishment did not affect nest survival probability and brood parasitism frequency of Indigo Bunting and Blue Grosbeak nests. Indigo Bunting/Blue Grosbeak nest success probability was more than twice as high in agriculture-dominated landscapes (39\%) than in forested landscapes (17\%), and brood parasitism frequency was high (33\%) but did not differ between landscapes. Edges in agriculture-dominated landscapes can be higher-quality habitats for early-succession birds than edges in forest-dominated landscapes, but our field border treatments did not enhance nest success for these birds on farms in either landscape.
\end{abstract}

RÉSUMÉ. Au cours des dernières décennies, de nombreux passereaux de début de succession ont subi un déclin marqué et généralisé, souvent lié à la destruction d'habitat. Les lisières de champs représentent de nouveaux milieux de début de succession ou s'ajoutent aux milieux de début de succession déjà existants dans les paysages agricoles. Toutefois, la configuration des lisières et le contexte paysager aux environs des fermes peuvent avoir une influence sur l'efficacité des lisières, en contribuant à la stabilisation ou à l'augmentation des populations d'oiseaux de début de succession. Nous avons examiné l'effet de lisières linéaires et non linéaires sur des fermes situées dans des paysages à dominance agricole ou forestière, sur deux paramètres du Passerin indigo (Passerina cyanea) et du Guiraca bleu (Passerina caerulea) : leur succès de nidification et leur taux de parasitisme par le Vacher à tête brune (Molothrus ater). La création de lisières n'a pas eu d'effets sur le taux de survie des nids, ni sur le taux de parasitisme. Le taux de survie des nids de Passerin indigo et de Guiraca bleu dans les paysages agricoles (39\%) était plus du double de celui observé dans les paysages forestiers (17\%). Le taux de parasitisme était élevé (33\%), mais ne différait pas entre les deux types de paysages. Les lisières présentes dans les paysages dominés par l'agriculture s'avèrent être des milieux de meilleure qualité pour les oiseaux de début de succession que ne le sont les

${ }^{1}$ University of Wisconsin - Stevens Point, ${ }^{2}$ North Carolina State University

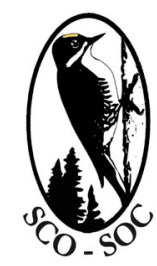

Sponsored by the Society of Canadian Ornithologists and Bird Studies Canada Parrainée par la Société des ornithologistes du Canada et Etudes d'oiseaux Canada

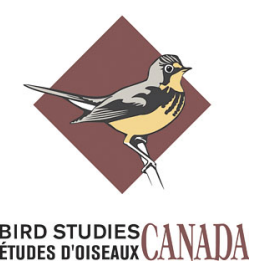


lisières présentes dans les paysages dominés par les forêts. Les traitements que nous avons effectués sur les lisières n'ont toutefois pas permis d'augmenter le succès de nidification de ces oiseaux dans l'un ou l'autre des deux types de paysages.

Key Words: early-succession birds; field borders; habitat shape; landscape context; nest parasitism; nest success

\section{INTRODUCTION}

Many early-succession bird species have experienced significant and widespread declines over the past several decades (e.g., Askins 1993, Brawn et al. 2001, Hunter et al. 2001). Historically, early-succession birds, e.g., Northern Bobwhite (Colinus virginianus), Grasshopper Sparrow (Ammodramus savannarum), Indigo Bunting (Passerina cyanea), and Bachman's Sparrow (Peucaea aestivalis), depended on naturally occurring disturbance in habitats such as grasslands, shrublands, and savannas (Brawn et al. 2001). Declines in early-succession birds have occurred because of destruction or alteration of earlysuccession habitats via intensive agriculture, closed-canopy pine plantations, urbanization, fire suppression, and disruption of flooding cycles and events (Klimstra 1982, Brennan 1991, Askins 1993, Roseberry 1993, Brawn et al. 2001, Hunter et al. 2001). Now, many of these birds primarily use human-created habitats, such as clearcuts, pasture, rangeland, and row crops.

Field borders may be used to create, supplement, or enhance early-succession habitat on private agricultural lands (Dimmick et al. 2002, Smith et al. $2005 a$ ). We use the term 'field border' to refer to areas of maintained herbaceous vegetation, i.e., grass and/or forbs, sometimes with a temporary shrub component, along field margins, established specifically for wildlife, but also providing other environmental benefits (Smith et al. 2005a). When field borders are managed for Northern Bobwhite and other early-succession bird species, they usually are disturbed with periodic selective herbicide application for woody vegetation control and/or with mowing, disking, or burning every two to three years to keep them in a perpetual state of earlysuccession. Field borders have the potential to benefit birds by creating nesting and brood-rearing habitat, escape cover, and foraging opportunities. For example, field borders have been shown to increase densities of wintering sparrows (Marcus et al. 2000, Smith et al. 2005a), early breeding season songbird nest density (Marcus 1998), breeding songbird abundance (Smith et al. 2005b), summer Northern Bobwhite abundance (Riddle et al. 2008), and Northern Bobwhite covey abundance (Puckett et al. 1995, Marcus 1998, Puckett et al. 2000, Palmer et al. 2005). Field borders also may enhance existing edge habitat. Linear strips of shrub habitat can soften hard forest edges, i.e., increase heterogeneity of edges by the addition or enhancement of an additional vegetation layer, and increase bird species richness and abundance (Morgan and Gates 1982, Fleming and Giuliano 1998). Herbaceous field borders with or without a shrub component may provide similar benefits. In the U.S., field border establishment and maintenance can be subsidized by federal and state programs such as the Conservation Reserve Program's Upland Bird Habitat Buffer (CP33; United States Department of Agriculture 2004) and North Carolina Wildlife Resources Commission's (NCWRC) Cooperative Upland habitat Restoration and Enhancement (CURE; Cobb et al. 2002). Government subsidies and the apparent benefits provided by field borders to a variety of bird species throughout the year make creation and maintenance of these habitats a potentially cost effective conservation solution for private landowners. However, little is known about how particular field border characteristics, such as shape or the surrounding landscape context, may influence their potential for songbird nest success.

Traditionally, field borders have been linear-shaped habitats to avoid alteration of farm activities (Stoddard 1931) or to minimize reductions in crop production (Morris 1998). However, narrow, linear habitats, because of their high edge-to-area ratios and the forest edges they may parallel, have the potential to act as population sinks for some birds by concentrating nest depredation and brood parasitism (e.g., Gates and Gysel 1978, Basore et al. 1986, Johnson and Temple 1990, Yosef 1994). 
Several studies have demonstrated increased numbers of birds or nests in linear habitats in agricultural settings (Shalaway 1985, Basore et al. 1986, Bryan and Best 1991, Smith et al. 2005b). Nest predators such as raccoons (Procyon lotor), striped skunks (Mephitis mephitis), and snakes may actively search linear habitats and field edges because of high nest densities, or may use linear habitats or edges as travel lanes and find nests incidentally (Crabtree et al. 1989, Durner and Gates 1993, Pedlar et al. 1997, Dijak and Thompson 2000). Therefore, birds that nest in linear habitats on farms may be especially vulnerable to nest depredation (but see Shalaway 1985). One potential solution to this problem is concentrating the same area of habitat into a nonlinear border, which may help reduce negative edge effects by decreasing edge-to-area ratios (Johnson and Temple 1990).

Habitat patches and edges can be influenced by landscape context (Andren 1995, Donovan et al. 1997). Thus, the effectiveness of local management efforts, such as field borders, may vary depending on the landscape context in which they occur. Bird abundance, nest survival, and brood parasitism rates in conservation buffers, strip vegetation, or grassland fragments can be influenced by landscape-level features such as the amount and proximity of woodlands (e.g., Arnold 1983, Johnson and Temple 1990). Similarly, nest depredation and brood parasite abundance along forest edges can be influenced by the amount of forest or agriculture in the surrounding landscape (Donovan et al. 1997).

Landscape context may become an increasingly important criterion for field border establishment for Northern Bobwhite in many areas of the United States (Roseberry and Sudkamp 1998, Riddle et al. 2008). For example, Riddle et al. (2008) demonstrated that Northern Bobwhite populations increased more after the establishment of field borders on farms in agriculture-dominated landscapes than in forest-dominated landscapes. Indeed, in the U.S., NCWRC already limits enrollment in the CURE program to landowners in landscapes with high percentages of row crop agriculture. However, field borders often are established along field-forest edges, which many researchers view as potential ecological traps for songbirds, especially in agricultural settings (Gates and Gysel 1978, Heske et al. 1999). Land managers may not be as eager to create early-succession habitat and enhance forest edges on farms for Northern Bobwhite if the landscapes in which these farms occur are deleterious for early-succession songbirds such as Indigo Buntings and Blue Grosbeaks (Passerina caerulea).

We examined nest success and brood parasitism rates of Indigo Buntings and Blue Grosbeaks on farms with linear and nonlinear field borders in landscapes dominated by either agriculture or forests. We hypothesized that nest success and the proportion of brood parasitized nests would be affected differently by the establishment of linear vs. nonlinear field borders and by the landscape context, i.e., agriculture-dominated vs. forestdominated, surrounding farms.

\section{METHODS}

\section{Study sites}

We studied field borders on 12 commercial hog farms owned by Murphy-Brown, LLC. Farms were located throughout the southern Coastal Plain of North Carolina in the following counties: Bladen, Duplin, Pender, Sampson, and Robeson (Fig. 1). The typical hog farm in eastern North Carolina consists of one or more hog houses, i.e., containment areas for hog production, lagoons for hog waste containment, and spray fields, i.e., row crop, hayfield, and/or pasture, for nutrient management. Our farms were selected from a pool of over 200 company farms to minimize potentially confounding differences among farms such as timber harvests and crop rotations. The farms in our study were all on a full or partial rotation of corn, soybeans, and wheat although a few farms occasionally grew cotton on some fields.

\section{Experimental design}

We employed a balanced $2 \times 2$ factorial design with field border shape, i.e., linear or nonlinear, and landscape context, i.e., agriculture- or forestdominated, as the two factors. Therefore, each treatment combination had 3 replicate farms. Field borders were established at the edges of row crop fields by allowing demarcated areas to go fallow after crop harvest. In 2004, field border locations were demarcated based on patterns of waste application, requirements for farm machinery operation, and advice given by farm technicians and other Murphy-Brown, LLC personnel. All field 
Fig. 1. Farm locations and treatment assignments in the Coastal Plain of North Carolina (2004-2006).

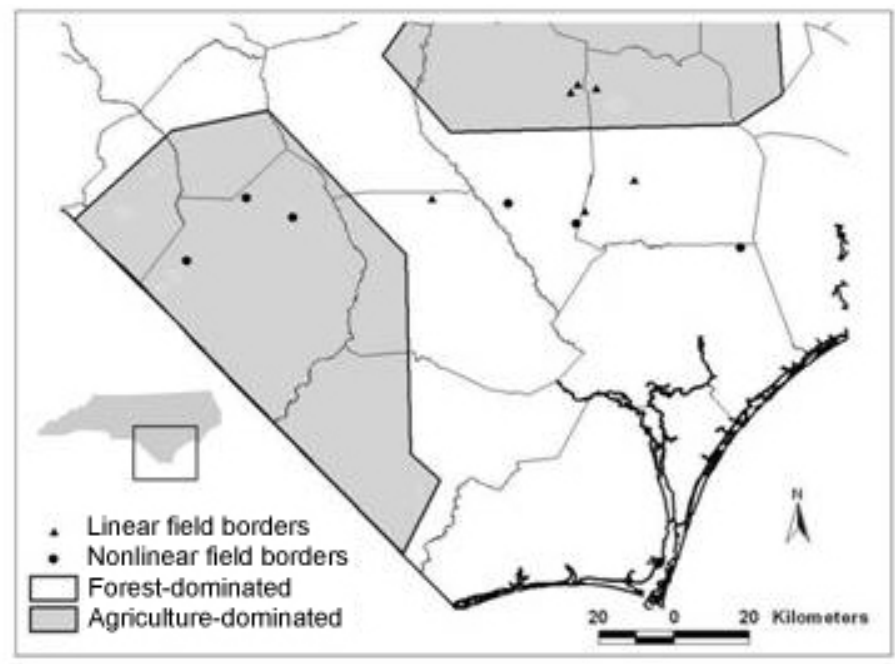

border habitats were out of crop production by the onset of the 2005 breeding season. Even though individual field border characteristics, e.g., area, and farm sizes varied, our goal was to standardize the relative amount of field border habitat among farms because the farm, and not the individual field or field border, was our unit of replication. Individual linear field borders were $\sim 3 \mathrm{~m}$ wide and varied by length (range $=66.40-1248.37 \mathrm{~m}$; mean $=377.79 ; \mathrm{SE}=38.19)$ and therefore area $(0.02-0.38$ ha; mean $=0.12 ; \mathrm{SE}=0.01$, whereas individual nonlinear field borders varied by shape and size $($ range $=0.05-2.48$ ha; mean $=0.26 ; \mathrm{SE}=0.07)$. Nonlinear field border shapes were typically triangular, semicircular, or amoeboid depending on whether or not they were located in a field with angular, e.g., square or rectangular, or curvilinear boundaries. Total row crop area/farm and total field border area/farm ranged from 17.01 to 127.13 ha (mean $=48.6 ; \mathrm{SE}=9.26)$ and 0.44 to 3.81 ha (mean $=1.25 ; \mathrm{SE}=0.27)$, respectively. Nevertheless, field borders comprised an average of $2.5 \%(\mathrm{SE}=0.08)$ of the total row cropped area on each farm and this did not differ by treatment. These farms were part of a larger study on the effects of landscape and field border shape on Northern Bobwhite. Field border vegetation characteristics among treatments were nearly identical in the larger study and detailed descriptions and comparisons may be found in Riddle et al. (2008).
Farms were selected from landscapes that were designated as either focal areas or nonfocal areas primarily for Northern Bobwhite, but also for earlysuccession songbird management, by the NCWRC for their CURE program (Cobb et al. 2002). Howell et al. (2002) provided a full description of the criteria and methodology used to identify and differentiate these landscapes for Bobwhite management. For the purposes of this study, we emphasize that focal areas generally are agriculture-dominated landscapes, row crops in particular, whereas nonfocal areas generally are forest-dominated landscapes. To confirm that this was the case for our 12 farms, we located a central point on each farm and determined the amount of row crop and forest within a circular buffer with a radius of $2538 \mathrm{~m}$ (buffer area $=2023$ ha). We used the same classification scheme with the same Landsat imagery as Howell et al. (2002) for this procedure. Farms in agriculture-dominated landscapes were surrounded by an average of 49.0 $\pm 2.8 \%$ (mean $\pm \mathrm{SE}$ ) row crops and $17.5 \pm 3.0 \%$ forests, whereas farms in forest-dominated landscapes were surrounded by an average of 18.1 $\pm 3.1 \%$ row crops and $48.4 \pm 6.5 \%$ forests. Therefore, the two landscapes were nearly perfect complements of each other with regard to the two parameters of interest.

We were not able to randomize field border shape on farms in either landscape because of the 
constraints imposed by hog waste application patterns and regulatory requirements. However, the pre vs. posttreatment contrasts we were able to perform were robust to our lack of randomization (Morrison et al. 2001). Comparisons of response variables between landscapes were not as robust to nonrandomization and inferences from these test results may not be as powerful as in our before and after comparisons.

\section{Data collection}

We located and monitored bird nests on all farms. Farms were monitored from mid-May until the end of July in each year. In 2004, the pretreatment year, all potential early-succession nesting habitat on each farm was searched multiple times. This mainly involved searching forest edges and ditches along fields for nests. In 2005 and 2006, we expanded search efforts to include field border habitat as it became suitable for nesting. As in 2004, each farm was searched multiple times. In all years, we used a combination of systematic searches and behavioral cues to find nests. We monitored the nests of all species every three to five days. Very few birds actually nested in the field border habitat, probably because of the low occurrence of shrubs. Instead, most birds continued to nest in shrubs, small trees, and herbaceous vegetation along forest edges and ditches. However, we still considered the establishment and shape of field borders in our analysis because border shape still may have influenced nest survival via the potential effects on edge vegetation structure and predator movements along edges.

\section{Analysis}

We focused on Indigo Bunting and Blue Grosbeak nests because they were the most common earlysuccession species nesting on our farms. We combined Indigo Bunting and Blue Grosbeak nests for analysis because they often were difficult to distinguish in the field without visual identification of adults. They also nested in similar locations and in the same plant species on our study sites. Nest survival probabilities were calculated for each farm using the Mayfield method to calculate a daily nest survival rate and then raising that to the average number of days (22) in the Indigo Bunting/Blue Grosbeak nesting cycle (Mayfield 1961, Mayfield 1975, Payne 1992, Ingold 1993). The proportion of brood parasitized nests was calculated for each farm by dividing the number of parasitized Bunting and Grosbeak nests by the total number of Bunting and Grosbeak nests on that farm. We analyzed nest survival probabilities and the proportion of brood parasitized nests using a 2 × 2 split-plot ANOVA (PROC GLM; SAS) with landscape context and habitat shape as whole-plot factors. The split-plot factor was year, i.e., the pretreatment year and the weighted average of the two posttreatment years. One-tailed preplanned orthogonal contrasts were used, in the absence of a landscape context*habitat shape*year interaction, to test for an overall effect of field borders, i.e., nest success and parasitism rates before field border establishment vs. after field border establishment. We also used one-tailed preplanned orthogonal contrasts to compare nest success and parasitism rates before and after field border establishment for both levels of each factor. Least-squares means are reported for all analyses. We did not use arcsine transformations in the following analyses because many of the response variable values were not extreme, i.e., $0-30 \%$ or 70-100\% (Zar 1999). However, we did confirm that the same conclusions would be made with arcsine transformations. Nevertheless, we simply report the analyses on the untransformed data for the convenience of the reader. We also recognize that a number of recent methods exist for analyzing nest success data (e.g., Dinsmore et al. 2002, Shaffer 2004). We opted to use the Mayfield method in this case because the farm, not the nest, was the unit of replication for our treatments and we were not interested in modeling covariates on individual nests. Other researchers have taken a similar approach with early-succession species in experimental settings (e.g., Weldon and Haddad 2005).

\section{RESULTS}

Over the course of the study, we located 166 Indigo Bunting/Blue Grosbeak nests. Sixty-three of these were parasitized by Brown-headed Cowbirds (Molothrus ater; Table 1).

There was no evidence for an interaction of landscape context, habitat shape, and year for nest survival probability $\left(\mathrm{F}_{1,8}=0.02, \mathrm{P}=0.8810\right)$ or the proportion of brood parasitized nests $\left(\mathrm{F}_{1.8}=0.36, \mathrm{P}\right.$ $=0.5661)$. Overall, nest survival probability and the proportion of brood parasitized nests did not change after the establishment of field borders (Table 2). 
Table 1. Total number of nests, exposure days, failures, and parasitized nests in treatments, North Carolina (2004-2006).

\begin{tabular}{|c|c|c|c|c|c|c|c|c|}
\hline & \multicolumn{4}{|c|}{ Pretreatment } & \multicolumn{4}{|c|}{ Posttreatment } \\
\hline & Nests & $\begin{array}{l}\text { Exposure } \\
\text { days }\end{array}$ & Failures & $\begin{array}{c}\text { Parasitized } \\
\text { nests }\end{array}$ & Nests & $\begin{array}{l}\text { Exposure } \\
\text { days }\end{array}$ & Failures & $\begin{array}{c}\text { Parasitized } \\
\text { nests }\end{array}$ \\
\hline Agriculture-Dominated & 8 & 78.5 & 4 & 2 & 53 & 607 & 33 & 22 \\
\hline Forest-Dominated & 13 & 130 & 9 & 9 & 92 & 985 & 60 & 30 \\
\hline Linear Borders & 6 & 38.5 & 5 & 1 & 43 & 415.5 & 27 & 12 \\
\hline Nonlinear Borders & 15 & 170 & 8 & 10 & 102 & 1176.5 & 66 & 40 \\
\hline
\end{tabular}

There was no year*landscape interaction for nest survival probability $\left(\mathrm{F}_{1,20}=1.04, \mathrm{P}=0.3381\right)$ or the proportion of brood parasitized nests $\left(\mathrm{F}_{1,20}=0.63\right.$, $\mathrm{P}=0.4510)$. Across all years, nest survival probabilities were more than twice as high in agriculture-dominated landscapes (mean $=0.39 ; \mathrm{SE}$ $=0.09$ ) than in forest-dominated landscapes (mean $=0.17 ; \mathrm{SE} 0.09 ; \mathrm{F}_{1,8}=7.67, \mathrm{P}=0.0243 ;$ Fig. 2). Overall the proportion of brood parasitized nests was $0.33(\mathrm{SE}=0.07)$, but it did not differ between agriculture-dominated and forest-dominated landscapes (Fig. 2).

\section{DISCUSSION}

Field border establishment did not affect Indigo Bunting/Blue Grosbeak nest survival probabilities or the proportion of brood parasitized nests on our farms. Similarly, Marcus (1998) failed to detect differences in daily survival rates between nests on farms with or without field borders. Few Buntings and Grosbeaks actually nested in field borders in our study area or in that of Marcus (1998). Although field border shape may have been an important determinant of nest survival for individual nests actually in the borders, the primary benefit of our borders to Buntings and Grosbeaks nesting outside of the actual borders on field edges would have been softening of existing field-forest edges, i.e., increased heterogeneity of edges by the addition or enhancement of an herbaceous layer. Indigo
Buntings and Blue Grosbeaks will nest in herbaceous vegetation, shrubs, small trees, and low branches on larger trees (Payne 1992, Ingold 1993). In general, field borders may have contained too little woody $(2.80 \%$; $\mathrm{SE}=0.67)$ vegetation to provide additional nesting sites for Buntings and Grosbeaks. Also, our field borders were dominated by dog fennel (Eupatorium capillifolium), which very rarely was used by Buntings or Grosbeaks as a nesting substrate (Riddle 2007).

The nest success probability for Indigo Bunting/ Blue Grosbeak was higher on farms in agriculturedominated landscapes (39\%) than on farms in forest-dominated landscapes $(17 \%)$. Our estimate of nest success for Indigo Bunting/Blue Grosbeak in agriculture-dominated landscapes was similar to that of Marcus (1998) for Indigo Bunting (39\%) and Blue Grosbeak (41\%). Weldon (2004) reported an Indigo Bunting nest success probability of $31 \%$ (averaged across treatments) in shrubby patches in a heavily forested matrix at the Savannah River Site in South Carolina. Indigo Bunting nest success was $21 \%$ in burned pine forests in the Georgia piedmont (White et al. 1999). Collectively, our results and those of Marcus (1998) suggest that agriculturedominated landscapes provide high quality habitats for birds such as Indigo Bunting and Blue Grosbeak when compared with nest success rates from forested landscapes in the southeastern U.S. However, more information is needed regarding individual female fecundity and fledgling survival in our study area. 
Table 2. Least-squares means (SE) of Indigo Bunting (Passerina cyanea) / Blue Grosbeak (Passerina caerulea) nest survival probabilities and the proportion of brood parasitized nests on farms, North Carolina (2004-2006).

Field Border Establishment

\begin{tabular}{|c|c|c|c|c|}
\hline & & & \multirow[b]{2}{*}{$\mathrm{t}_{8} \dagger+$} & \multirow[b]{2}{*}{$\mathrm{P} \S$} \\
\hline & Pre & Post & & \\
\hline \multicolumn{5}{|c|}{ Nest survival probabilities } \\
\hline Agriculture-dominated & $0.44(0.15)$ & $0.34(0.11)$ & 0.5388 & 0.5960 \\
\hline Forest-dominated & $0.09(0.15)$ & $0.26(0.11)$ & 0.8600 & 0.4000 \\
\hline Nonlinear borders & $0.36(0.15)$ & $0.29(0.11)$ & 0.3854 & 0.7043 \\
\hline Linear borders & $0.17(0.15)$ & $0.31(0.11)$ & 0.7098 & 0.4862 \\
\hline Overall & $0.26(0.11)$ & $0.30(0.08)$ & 0.2332 & 0.8178 \\
\hline \multicolumn{5}{|c|}{ Proportion of brood parasitized nests } \\
\hline Agriculture-dominated & $0.25(0.16)$ & $0.33(0.11)$ & 0.3854 & 0.7045 \\
\hline Forest-dominated & $0.45(0.16)$ & $0.31(0.11)$ & 0.7065 & 0.4876 \\
\hline Nonlinear borders & $0.54(0.16)$ & $0.37(0.11)$ & 0.7984 & 0.4345 \\
\hline Linear borders & $0.17(0.16)$ & $0.26(0.11)$ & 0.4778 & 0.6385 \\
\hline Overall & $0.35(0.11)$ & $0.32(0.08)$ & 0.2319 & 0.8190 \\
\hline
\end{tabular}

$\dagger$ Absolute value of observed t statistic.

$\ddagger$ All tests are one-tailed.

§Probability of observing the associated, or larger, $\mathrm{t}$ statistic.

We suggest that nest success in agriculturedominated landscapes was high because lack of forest cover may have limited important nest predators. In particular, we believe snakes were the primary nest predator because most depredated nests were placed between 1 and $2 \mathrm{~m}$ from the ground in small salt myrtle (Baccharis halimifolia) branches (J. D. Riddle, personal observation) where dexterous mesomammals such as raccoons could not reach them without climbing or manipulating the vegetation. In salt myrtle, this would have caused noticeable plant and nest damage, which was not observed in most cases. We observed snakes, such as the black rat snake (Elaphe obsoleta), along field edges and in shrubs. Black rat snakes may encounter nests in and around the forest margins they use for thermoregulation, foraging, and travel. Several studies suggest the ideal landscape for a black rat snake is likely a mosaic of small fields interspersed with forest (Weatherhead and Charland 1985, Durner and Gates 1993, Blouin-Demers and Weatherhead 2001). The numerous large fields and low amount of forest cover $(18.5 \%)$ in agriculturedominated landscapes may be insufficient to support black rat snakes to the same degree as forestdominated landscapes. Durner and Gates (1993) suggested that high percentages of row crop decrease the suitability of landscapes for black rat 
Fig. 2. Least-squares means and 95\% CI for Indigo Bunting (Passerina cyanea) / Blue Grosbeak (Passerina caerulea) nest success probabilities and the proportion of brood parasitized nests on farms in agriculture- and forest-dominated landscapes, North Carolina (2004-2006).

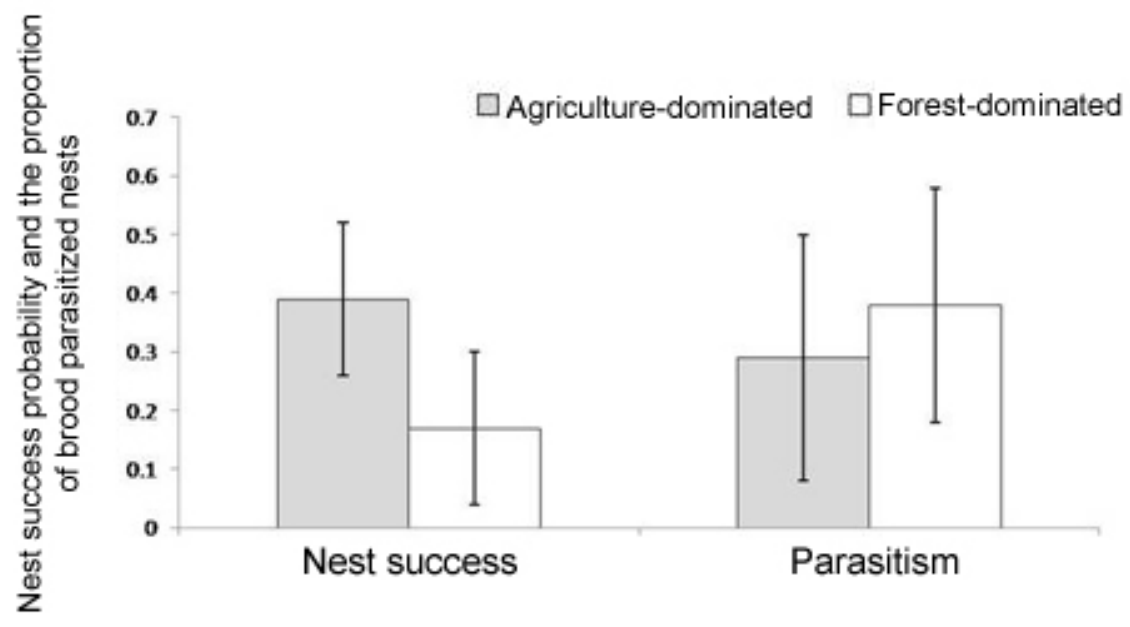

snakes because they are not used for travel or foraging, and probably expose the snakes to greater risk of predation (see also Keller and Heske 2000). It is also possible that corvids depredated some nests, which could have been difficult to distinguish from snake depredation (Thompson and Burhans 2003). However, corvids may be less common nest predators than snakes in a shrubby environment (Thompson and Burhans 2003). Additionally, corvids did not appear to be more abundant on farms in forest-dominated landscapes than on farms in agriculture-dominated landscapes in our study ( $\mathrm{J}$. D. Riddle, unpublished data).

Our overall estimate of brood parasitism (33\%) did not differ between landscapes with markedly different amounts of forest cover, and was high when compared with other studies in the southeastern U.S. For example, Marcus (1998) reported only $5.9 \%$ of nests parasitized by Brownheaded Cowbirds. In old-field habitat on James Island, South Carolina, Bunting and Grosbeak parasitism levels were $11.1 \%$ and $23.5 \%$, respectively (Whitehead et al. 2002). Kilgo and Moorman (2003) reviewed parasitism rates for several known Cowbird hosts in forested areas $(\geq$ $80 \%$ forests) in the southeastern Coastal Plain, and reported average parasitism levels of $17.2 \%$ and $0 \%$ for Indigo Buntings and Blue Grosbeaks, respectively. However, they addressed the need for more work in areas of the Coastal Plain where agriculture was a more prevalent landscape feature (Kilgo and Moorman 2003). Our results suggest higher parasitism levels are possible in agricultural areas in the southeastern U.S. than reported previously. We suggest farm operations specific to our study sites may have attracted Brown-headed Cowbirds. Hog farms usually have one to two covered grain bins for every hog house. Spillage as feed trucks fill these bins provides foraging opportunities for Cowbirds and may indirectly increase parasitism rates nearby. Regardless, brood parasitism by Brown-headed Cowbirds in the southeastern U.S. deserves more attention than previously thought (e.g., Wiedenfeld 2000), and could be especially harmful for single-brooded species, such as the Yellow-breasted Chat (Icteria virens; Whitehead et al. 2002).

\section{CONCLUSION}

Multiple authors have addressed the need for a landscape-level approach to avian conservation (Freemark et al. 1995, Petit et al. 1995, Donovan et al. 1997, Heske et al. 2001). Landscape-level patterns in nest success, predator communities, and brood parasites can differ for individual bird 
species, guilds, and between and within regions (Donovan et al. 1997, Woodward et al. 2001). The need has been emphasized for manipulative and comparative studies within and between regions to identify areas where landscape-level patterns are favorable for target species and therefore most conducive to local management activities. This need is particularly great with regard to agriculturally fragmented landscapes and farmland habitat structures such as field borders (Freemark et al. 1995, Heske et al. 2001).

We were unable to document any effects of field border establishment on early-succession songbirds, probably because too little field border habitat was created on individual farms. Additionally, the sample size of farms was relatively small which may have increased Type II error rates. Regardless, the field borders we established likely contained too little of a woody component to be attractive nest sites for Indigo Buntings and Blue Grosbeaks. Given the early stages of our field border habitat, perhaps it would have been helpful to include Common Yellowthroats (Geothlypis trichas), or other songbirds which prefer grassy and herbaceous-dominated habitats in our focal species group. Based on the nest survival probabilities we observed, it appears that agriculture-dominated landscapes can have greater management potential than forest-dominated landscapes for Indigo Buntings and Blue Grosbeaks. Future studies on the use of field borders as management tools for these birds should be performed across time periods long enough to promote shrub development; also, these studies should attempt to identify the landscapelevel mechanisms in agriculture-dominated landscapes that favor high nest success probabilities for Indigo Buntings and Blue Grosbeaks.

Responses to this article can be read online at:

http://www.ace-eco.org/vol5/iss2/art9/responses/

\section{Acknowledgments:}

We thank ourfield technicians F. Perkins, A. Savage, W. Ricks, C. Reddy, J. Remmington, K. Yantis, S. Long, and A. Sabatine for many long hours in the field. F. Perkins also cosupervised several technicians and helped coordinate research activities. D. Williamson, K. Westerbeak, and all of the Murphy-Brown, LLC staff provided invaluable assistance in farm selection, farm access, field border location, and other study logistics. A. Oswald and family and Murphy Family Farms provided housing. T. Sharpe provided technical advice and encouragement. K. Pollock provided invaluable statistical advice and helpful comments on this manuscript. P. Bromley, D. Cobb, N. Haddad, S. Nelson, and T. Simons also provided helpful comments on this manuscript. This project was supported financially by the Department of Forestry and Environmental Resources and the Fisheries and Wildlife Sciences Program at North Carolina State University, the North Carolina Wildlife Resources Commission, Murphy-Brown, LLC, and a grant from the USDA-NRCS/Mississippi State University Bobwhite Restoration Project.

\section{LITERATURE CITED}

Andren, H. 1995. Effects of landscape composition on predation rates at habitat edges. Pages 225-255 in L. Hansson, L. Fahrig, and G. Merriam, editors. Mosaic Landscapes and Ecological Processes. Chapman and Hall, London, UK.

Arnold, G. W. 1983. The influence of ditch and hedgerow structure, length of hedgerows, and area of woodland and garden on bird numbers on farmland. Journal of Applied Ecology 20:731-750.

Askins, R. A. 1993. Population trends in grassland, shrubland, and forest birds in eastern North America. Current Ornithology 11:1-34.

Basore, N. S., L. B. Best, and J. B. Wooley, Jr. 1986. Bird nesting in Iowa no-tillage and tilled cropland. Journal of Wildlife Management 50:19-28.

Blouin-Demers, G., and P. J. Weatherhead. 2001. Habitat use by black rat snakes (Elaphe obsoleta obsoleta) in fragmented forests. Ecology 82:2882-2896.

Brawn, J. D., S. K. Robinson, and F. R. Thompson, III. 2001. The role of disturbance in the ecology and conservation of birds. Annual Review of Ecology and Systematics 32:251-276.

Brennan, L. A. 1991. How can we reverse the northern bobwhite population decline? Wildlife Society Bulletin 19:544-555. 
Bryan, G. G., and L. B. Best. 1991. Bird abundance and species richness in grassed waterways in Iowa rowcrop fields. American Midland Naturalist 126:90-102.

Cobb, D. T., T. L. Sharpe, D. Sawyer, and D. O. Baumbarger. 2002. Integrating early-successional wildlife and habitats into North Carolina's 21st century landscape. Proceedings of the Annual Conference of the Southeastern Association of Fish and Wildlife Agencies 56:124-135.

Crabtree, R. L., L. S. Broome, and M. L. Wolfe. 1989. Effect of habitat characteristics on gadwall nest predation and nest-site selection. Journal of Wildlife Management 53:129-137.

Dijak, W. D., and F. R. Thompson, III. 2000. Landscape and edge effects on the distribution of mammalian predators in Missouri. Journal of Wildlife Management 64:209-216.

Dimmick, R. W., M. J. Gudlin, and D. F. McKenzie. 2002. The northern bobwhite conservation initiative. Miscellaneous publication of the Southeastern Association of Fish and Wildlife Agencies, South Carolina, USA.

Dinsmore, S. J., G. C. White, and F. L. Knopf. 2002. Advanced techniques for modeling avian nest survival. Ecology 83:3476-3488.

Donovan, T. M., P. W. Jones, E. M. Annand, and F. R. Thompson, III. 1997. Variation in local-scale edge effects: mechanisms and landscape context. Ecology 78:2064-2075.

Durner, G. M., and J. E. Gates. 1993. Spatial ecology of black rat snakes on Remington Farms, Maryland. Journal of Wildlife Management 57:812-826.

Fleming, K. K., and W. M. Giuliano. 1998. Effect of border-edge cuts on birds at woodlot edges in southwestern Pennsylvania. Journal of Wildlife Management 62:1430-1437.

Freemark, K. E., J. B. Dunning, S. J. Hejl, and J. R. Probst. 1995. A landscape ecology perspective for research, conservation, and management. Pages 381-427 in T. E. Martin and D. M. Finch, editors. Ecology and Management of Neotropical Migratory Birds. Oxford University Press, New York, New York, USA.
Gates, J. E., and L. W. Gysel. 1978. Avian nest dispersion and fledging success in field-forest ecotones. Ecology 59:871-883.

Heske, E. J., S. K. Robinson, and J. D. Brawn. 1999. Predator activity and predation on songbird nests on forest-field edges in east-central Illinois. Landscape Ecology 14:345-354.

Heske, E. J., S. K. Robinson, and J. D. Brawn. 2001. Nest predation and neotropical migrant songbirds: piecing together the fragments. Wildlife Society Bulletin 29:52-61.

Howell, D. L., D. T. Cobb, and T. L. Sharpe. 2002. Selection of focal areas for northern bobwhite enhancement on private lands in North Carolina. Proceedings of the Annual Conference of the Southeastern Association of Fish and Wildlife Agencies 56:159-170.

Hunter, W. C., D. A. Buehler, R. A. Canterbury, J. L. Confer, and P. B. Hamel. 2001. Conservation of disturbance-dependent birds in eastern North America. Wildlife Society Bulletin 29:440-455.

Ingold, J. L. 1993. Blue grosbeak (Guiraca caerulea). In A. Poole, P. Stettenheim, and F. Gill, editors. The birds of North America, no 79. Academy of Natural Sciences, Philadelphia, and American Ornithologists' Union, Washington, D. C., USA.

Johnson, R. G, and S. A. Temple. 1990. Nest predation and brood parasitism of tallgrass prairie birds. Journal of Wildlife Management 54:106-111.

Keller, W. L., and E. J. Heske. 2000. Habitat use by three species of snakes at the Middle Fork Fish and Wildlife Area, Illinois. Journal of Herpetology 34:558-564.

Klimstra, W. D. 1982. Bobwhite quail and changing land use. Proceedings of the National Bobwhite Quail Symposium 2:1-5.

Kilgo, J. C., and C. E. Moorman. 2003. Patterns of cowbird parasitism in the southern Atlantic coastal plain and piedmont. Wilson Bulletin 115:277-284.

Marcus, J. F. 1998. The effects of predation and habitat improvement on farmland birds. Thesis, 
North Carolina State University, Raleigh, North Carolina, USA.

Marcus, J. F., W. E. Palmer, and P. T. Bromley. 2000. The effects of farm field borders on overwintering sparrow densities. Wilson Bulletin 112:517-523.

Mayfield, H. F. 1961. Nesting success calculated from exposure. Wilson Bulletin 73:255-261.

Mayfield, H. F. 1975. Suggestions for calculating nest success. Wilson Bulletin 87:456-466.

Morgan, K. A., and J. E. Gates. 1982. Bird population patterns in forest edge and strip vegetation at Remington Farms, Maryland. Journal of Wildlife Management 46:933-944.

Morris, J. T. 1998. Conservation decisions of agricultural producers in eastern North Carolina. Dissertation, North Carolina State University, Raleigh, North Carolina, USA.

Morrison, M. L., W. M. Block, M. D. Strickland, and W. L. Kendall. 2001. Wildlife Study Design. Springer, New York, New York, USA.

Palmer, W. E., S. D. Wellendorf, J. R. Gillis, and P. T. Bromley. 2005. Effect of field borders and nest-predator reduction on abundance of northern bobwhites. Wildlife Society Bulletin 33:1398-1405.

Payne, R. B. 1992. Indigo bunting (Passerina cyanea). In A. Poole, P. Stettenheim, and F. Gill, editors. The birds of North America, no 4. Academy of Natural Sciences, Philadelphia, and American Ornithologists' Union, Washington, D.C., USA.

Pedlar, J. H., L. Fahrig, and H. G. Merriam. 1997. Raccoon habitat use at 2 spatial scales. Journal of Wildlife Management 61:102-112.

Petit, L. J., D. R. Petit, and T. E. Martin. 1995. Landscape-level management of migratory birds: looking past the trees to see the forest. Wildlife Society Bulletin 23:420-429.

Puckett, K. M., W. E. Palmer, P. T. Bromley, J. R. Anderson, Jr., and T. L. Sharpe. 1995. Bobwhite nesting ecology and modern agriculture: a management experiment. Proceedings of the Annual Conference of the Southeastern Association of Fish and Wildlife Agencies 49:505-515.
Puckett, K. M., W. E. Palmer, P. T. Bromley, J. R. Anderson, Jr., and T. L. Sharpe. 2000. Effects of filter strips on habitat use and home range of northern bobwhites on Alligator River National Wildlife Refuge. Proceedings of the National Bobwhite Quail Symposium 4:26-31.

Riddle, J. D. 2007. Maximizing the impact of field borders for quail and early-succession songbirds: what's the best design for implementation? Dissertation, North Carolina State University, Raleigh, North Carolina, USA.

Riddle, J. D., C. E. Moorman, and K. H. Pollock. 2008. The importance of habitat shape and landscape context to northern bobwhite populations. Journal of Wildlife Management 72:1376-1382.

Roseberry, J. L. 1993. Bobwhite and the "new" biology. Proceedings of the National Bobwhite Quail Symposium 3:16-20.

Roseberry, J. L., and S. D. Sudkamp. 1998. Assessing the suitability of landscapes for northern bobwhite. Journal of Wildlife Management 62:895-902.

SAS Institute 2006. Version 9.1.3. SAS Institute, Cary, North Carolina, USA.

Shaffer, T. L. 2004. A unified approach to analyzing nest success. Auk 121:526-540.

Shalaway, S. D. 1985. Fencerow management for nesting birds in Michigan. Wildlife Society Bulletin 13:302-306.

Smith, M. D., P. J. Barbour, L. W. Burger, Jr., and S. J. Dinsmore. 2005a. Density and diversity of overwintering birds in managed field borders in Mississippi. Wilson Bulletin 117:258-269.

Smith, M. D., P. J. Barbour, L. W. Burger, Jr., and S. J. Dinsmore. 2005b. Breeding bird abundance and diversity in agricultural field borders in the Black Belt Prairie of Mississippi. Proceedings of the Annual Conference of the Southeastern Association of Fish and Wildlife Agencies 59:43-56.

Stoddard, H. L. 1931. The bobwhite quail: its habits, preservation, and increase. Third edition. Charles Scribner's Sons, New York, New York, USA. 
Thompson, F. R., and D. E. Burhans. 2003. Predation of songbird nests differs by predator and between field and forest habitats. Journal of Wildlife Management 67:408-416.

United States Department of Agriculture. 2004. Farm Service Agency, Notice CRP-479. Washington, D.C., USA

Weatherhead, P. J., and M. B. Charland. 1985. Habitat selection in an Ontario population of the snake, Elaphe obsoleta. Journal of Herpetology 19:12-19.

Weldon, A. J. 2004. The effects of patch shape and connectivity on nest site selection and reproductive success of the indigo bunting. Thesis, North Carolina State University, Raleigh, North Carolina, USA.

Weldon, A. J., and N. M. Haddad. 2005. The effects of patch shape on indigo buntings: evidence for an ecological trap. Ecology 86:1422-1431.

White, D. H., B. R. Chapman, J. H. Brunjes, IV, R. V. Raftovich, Jr., and J. T. Seginak. 1999. Abundance and reproduction of songbirds in burned and unburned pine forests of the Georgia Piedmont. Journal of Field Ornithology 70:414-424.

Whitehead, M. A., S. H. Schweitzer, and W. Post. 2002. Cowbird/host interactions in a southeastern old-field: a recent contact area? Journal of Field Ornithology 73:379-386.

Wiedenfeld, D. A. 2000. Cowbird population changes and their relationship to changes in some host species. Pages 35-46 in J. N. M. Smith, T. L. Cook, S. I. Rothstein, S. K. Robinson, and S. G. Sealy, editors. Ecology and management of cowbirds and their hosts. University of Texas Press, Austin, Texas, USA.

Woodward, A. A., A. D. Fink, and F. R. Thompson, III. 2001. Edge effects and ecological traps: effects on shrubland birds in Missouri. Journal of Wildlife Management 65:668-675.

Yosef, R. 1994. The effects of fencelines on the reproductive success of loggerhead shrikes. Conservation Biology 8:281-285.
Zar, J. H. 1999. Biostatistical analysis. Fourth edition. Prentice-Hall, Upper Saddle River, New Jersey, USA. 